\title{
THE BIOLOGICAL EFFECTS OF CORAL WITH ADIPOSE DERIVED STEM CELLS ON MANDIBULAR BONY DEFECT IN ALBINO RATS
}

\author{
Nada Nawwar ${ }^{*}$, Rehab Rizk El Zehary ${ }^{* *}$, Saied El Attar ${ }^{* *}$ and Mahitabe Elgamily ${ }^{* * *}$
}

\begin{abstract}
Objective: To evaluate the biological effects of coral scaffold with or without adipose derived stem cells (ADSCs) on healing of bony defects in albino rats.

Methods: Fifty four male albino rats weighing approximately 250-300 gm were selected and randomly divided into 3 groups. Each rat received one bone defect on the left side of mandible near the diastema. The defects were either left empty (group A) n=18, treated with coral only (group B) $\mathrm{n}=18$ or received a combination of coral and adipose derived stem cells (group C) $n=18$ which were harvested from the rats peri renal region. Bone healing was evaluated using heamatoxylin and eosin and trichrome stain, then the results were subjected to digital image analysis followed by one- way ANOVA statistical analysis.
\end{abstract}

Results: Bony defects received the combination of coral scaffold and stem cells show better healing in respect to the quantity and the quality of the newly formed bone.

Conclusion: ADSCs loaded onto coral granule scaffold have ameliorating effect on the repair of the mandibular defects in rat model.

KEY WORDS: Bone defect, Coral, Adipose derived stem cells, scaffold, Trichrome.

\section{INTRODUCTION}

Bone defects in the maxillofacial region may be attributed to periodontal disease, osteomyelitis, trauma and cysts. The defects may occur also after tumors removal, dentoalveolar, orthognathic and implant surgeries. With the purpose of reconstructing those bone defects, numerous techniques, such as using bone grafts, have been developed. As a result of the short comings of autografts (iliac crest and rib grafts) due to pain and morbidity at the donor site, accessibility of tissue, and working in two operative fields, and allografts such as graft rejection and possible disease spread, synthetic bone grafts and

* Demonstrator of Oral Biology Faculty of Dentistry, Horus University, Egypt.

** Assistant Professor of Oral Biology, Faculty of Dentistry, Mansoura University, Egypt.

***Lecturer of Oral Biology, Faculty of Dentistry, Mansoura University, Egypt. 
autologous source of progenitor bone cells are of great importance for bone tissue engineering. ${ }^{(1)}$

Corals are marine invertebrates with nearly seven thousand species and can be categorized as soft corals (lacking inorganic structure) and hard corals The hard corals usually live in compact colonies of many identical individual polyps. Calcicoblasts are cells present on the outer layer of the corals, they are similar to osteoblasts in producing a rigid outer skeleton formed of calcium carbonate that protects the organism and gives it strength. Natural sourced ceramics such as coralline based ceramics have been utilized in bone tissue engineering field. ${ }^{(2-3)}$

Natural coral skeleton (NCS) has unique micro-topography of the surface, biocompatibility, osteoconduction, and bioactivity that may enhance the biodegradation and neo-osteogenesis rates. These facts suggest using NCS as an implant for bone defect restoration and as $3 \mathrm{D}$ matrices for cultured cells for bone tissue engineering. ${ }^{(4)}$

Coral resorption is done by osteoclasts under the influence of carbonic anhydrase enzyme. Previous studies have revealed that coral resorption includes two phases: first, coral block edges become powdery and then are liquefied into the extracellular fluid and phagocytosed. ${ }^{(5)}$ Coralline based scaffolds are capable of supporting the attachment, proliferation and differentiation of MSCs and osteoblasts. (6) Current researches show that coral is not cytotoxic and stimulates cell growth. Seeded cells onto coral granules exhibited good attachment, spread and proliferation on the surface of the material. ${ }^{(7)}$

Adipose derived stem cells (ADMSCs) are non-hematopoietic mesenchymal stem cells that are sourced from the adipose tissue and have a multilineage potential. They are capable of differentiating into many mesodermal lineages such as bone, muscle, cartilage, and fat. They also retain the capacity to differentiate into non mesodermal lineage cells such as hepatocytes and neurogenic cells under the effect of appropriate signaling molecules and microenvironment. This mesodermal and ectodermal capacity means that adipose tissue represents a source of adult stem cells that can be utilized in the field of regenerative and replacement medicine. ${ }^{(8-9)}$

Human fat is a good source of ADMSCs and it is usually obtained from liposuction. ${ }^{(10)}$ These cells have no immunological barriers when isolated from the recipient and can be safely used as an autograft, consequently decreasing the risk of tissue rejection and infection. ${ }^{(11)}$ Site morbidity and low cell counts are vastly limited due to the ease of harvesting of ADSCs. The attainment of adipose tissue is much more economic and less invasive than bone marrow and the yield of stromal cells is much greater in adipose tissue. Thus, in the perspective of cell therapy, adipose tissue is considered as a rich, and attractive source of donor tissue for autologous cell replacement. ${ }^{(12)}$ So, coral with or without ADMSCs may have an impact on bone defect healing. ${ }^{(13)}$

\section{MATERIALS AND METHODS}

All the experimental procedures were performed in accordance with Mansoura University research ethics committee with approval number M0409109, and according to NIH guide for the care and use of laboratory animals eighth edition 2011. The study was conducted in experimental animal study laboratory of Mansoura University.

Sample size was calculated by the G*Power (Version 3.1.9.2), with $\alpha$ error 5\% and a power of $80 \%$, using medium effect size 0.32 , number of groups was 3, number of measures was 3 , using ANOVA model, repeated measures within- between interaction. A priori: Computed required sample size was 18 subjects per group (total 54 subjects). ${ }^{(14)}$

\section{Animals}

Fifty four adult male, pathogen free, white albino, Sprague Dawley rats weighing approximately 250-300 gm and 2.5-3 months of age were used. They were acclimatized for at least 3 days before starting the study. The animals were housed in 
individual polypropylene cages and kept in $12 \mathrm{~h}$ light/dark cycles and controlled conditions $\left(22 \pm 3^{\circ} \mathrm{C}\right.$ temperature, $55-60 \%$ relative humidity). All rats had free access to standard pelleted diet of rodents and tap water. The rats were randomly divided into 3 groups each rat received one bone defect on left side of mandible near the diastema using leader ${ }^{\circledR}$ trephine drill $3.6 \mathrm{~mm}$ diameter under continuous saline flush cooling.

Group A $(\mathrm{n}=18)$ (negative control group): The bone defects left empty.

Group B ( $\mathrm{n}=18)$ (positive control group): The bone defects filled with coral only.

Group C ( $\mathrm{n}=18)$ : The bone defects filled with a combination of coral and adipose derived Stem cells (topically applied). ${ }^{(15)}$

Six animals of each group were sacrificed at $1^{\text {st }}$, $4^{\text {th }}$ and $8^{\text {th }}$ week post-surgery by overdose of diethyl ether.

\section{Surgical procedures}

All rats fasted 24 hours before the procedures, they were anesthetized using intravenous injection of ketamine $(25 \mathrm{mg} / \mathrm{kg})$ and xylazine $(5 \mathrm{mg} / \mathrm{kg})$ Egyptian Inter Pharmaceutical Industries Co, 10th Ramadan City, Egypt

- The fur on the neck area was shaved, then disinfected using alcohol then betadine. ${ }^{(16)}$

- Incision was made in the skin of the mandible 2 $\mathrm{cm}$ in length, the area was cleaned with a gauze till mandibular bone was exposed.

- The defects were made using trephine bur $3.6 \mathrm{~mm}$ in diameter under continuous saline irrigation. After insertion of the coral granules or the ADMSCs plus coral into the defects, skin was sutured using non absorbable suture $3 / 0$ with interrupted suture. Then the skin was disinfected with betadine. Postoperatively, the rats were on antibiotic therapy for four days, with free access to water and standard diet.

\section{Coral scaffolds}

Natural coral was ground by ShatterBox ${ }^{\circledR}$ ring and puck milling machine then sieved with a sieve shaker to acquire small particles of 1-2 mm diameter. To remove foreign protein, the coral particles were soaked in 5\% sodium hypochlorite for three days. Then washed with distilled water and sterilized using autoclave. ${ }^{(17)}$ Acropora granules exposure to such sterilizing conditions does not affect their composition and structure. Coral granules were topically loaded into the bone defect. ${ }^{(18)}$

\section{Isolation and culture of rat ADSCS:}

Adipose derived stem cells were isolated from rats using the protocol done by Kuhbier JW et al (2010) and Liu G et al (2013). ${ }^{(19,20)}$

\section{Flow cytometry}

Flow cytometry was performed on a BD Accuri C6 flow cytometer. Antibodies were purchased from Bio Legend Europe (Fell, Germany). Expression of the following adipose-derived stromal cell markers was tested: CD 105, CD 13, and CD 45.

\section{Immunophenotype Characterization of adipose derived stem Cells}

Cells were characterized using cell surface markers by fluorescence-activated cell sorting (FACS) analysis. The cells were stained with different fluorescently labeled monoclonal antibodies (mAb). In brief, $5 \times 10^{5}$ cells (in $100 \mu \mathrm{l} \mathrm{PBS} / 0.5 \%$ $\mathrm{BSA} / 2 \mathrm{mmol} / \mathrm{EDTA})$ were mixed with $10 \mu \mathrm{l}$ of the fluorescently labeled primary monoclonal antibodies (CD45-, CD13+ and CD 105+) and incubated in the dark at $2 \sim 8^{\circ} \mathrm{C}$ for $30 \mathrm{~min}$. Washing with Phosphate Buffered saline (PBS) was done twice and the pellet was re-suspended in PBS and analyzed immediately on a BD Accuri C6 flow cytometer. A total of $5 \times 10^{5}$ adipose derived stem cells were incubated with (CD13, CD105, and CD45). DNA histogram derived from flow cytometry was obtained with a computer program for Dean and Jett mathematical analysis. ${ }^{(21)}$ 


\section{Seeding of stem cells onto coral granules: ${ }^{(22)}$}

- The process of seeding the stem cells on the coral granules was carried out in a biological safety cabinet to ensure sterile conditions.

- At the third passage (P3), sub confluent cells were trypsinized, and $2 \times 10^{5}$ cells were seeded onto the coral granules. The cell suspension was slowly pipetted onto the scaffold in a 96 well plate to draw the suspension bi-directionally three times.

- After incubation at $37^{\circ} \mathrm{C}$ for $4 \mathrm{~h}$ to allow the cells to attach to the scaffold, the coral/ADSCs composites were incubated in complete medium for $48 \mathrm{hrs}$.

\section{Examination Methods}

1- Scanning electronic microscope (SEM) was used to determine the adhesion of cells on the scaffolds at day 2 after cell seeding at a density of $2 \times 10^{5}$ cells per scaffold in regular culture medium. The constructs were fixed in $2.5 \%$ glutaraldehyde, postfixed with $0.1 \%$ osmium tetroxide, dehydrated through an ethanol series, dried in a $\mathrm{CO} 2$ dryer, coated with gold, and examined with (SEM). ${ }^{(23)}$

2- After scarification, the specimens were removed and fixed in $10 \%$ neutral buffered formalin. Samples were decalcified using Ethylene Diamine Tetra Acetic acid (EDTA) for histological examination. Specimens were evaluated histologically using hematoxylin-eosin and Masson's trichrome as special stains.

Slides were photographed using Olympus ${ }^{\circledR}$ digital camera installed on Olympus ${ }^{\circledR}$ microscope with $1 / 2 \mathrm{X}$ photo adaptor, using $100 \mathrm{X}$ objective. The result images were analyzed on Intel ${ }^{\circledR}$ Core I3 ${ }^{\circledR}$ based computer using Video Test Morphology ${ }^{\circledR}$ software (Russia) with a Specific built-in routine for area measurement.

\section{Statistical analysis}

1- One-way ANOVA (Analysis of variance) test was used as data were normally distributed in all groups. Post-hoc analysis (using LSD test) was performed whenever the result was significant to detect where that significant difference existed.

2- The two-way ANOVA was used to determine whether there is an interaction effect between two independent variables

\section{RESULTS}

\section{Characterization of ADSCs}

Adipose derived stem cells were successfully isolated by the enzymatic method. Inspecting the initial culture on the $7^{\text {th }}$ day of isolation using an inverted phase contrast microscope showed few fibroblast-like cells adhered to the flask and beginning of colonies formation that increased by day 11, while in day 17 the colonies could not be detected due to increased number of cells. (Fig.1A-C) The adherent cells reached 80-90\% confluence by 21 days. (Fig. 1D)

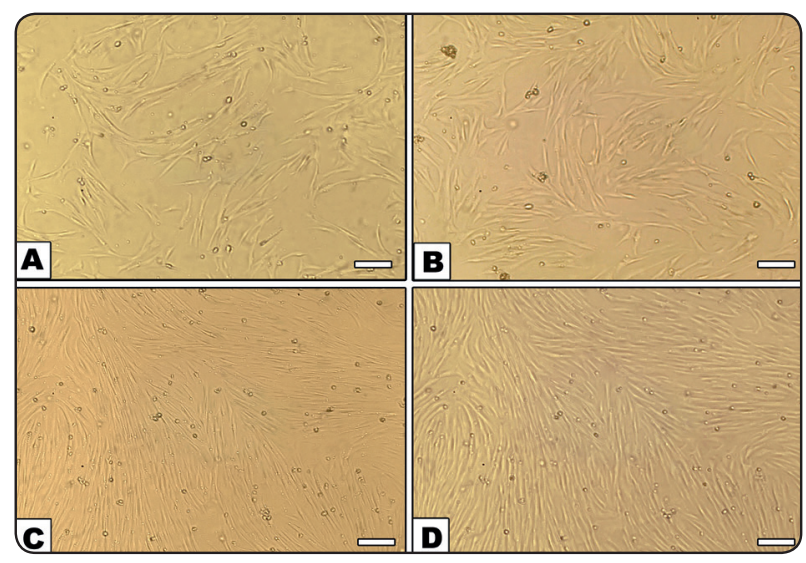

Fig. (1): Inverted microscope photographs showing, (A) few fibroblast-like cells adhered to the flask at the initial culture on the $7^{\text {th }}$ day of isolation and beginning of colonies formation with little cells in between. (B) Cell confluence on the $11^{\text {th }}$ day. (C) Cell confluence on the $17^{\text {th }}$ day. (D) Cell confluence on the $21^{\text {st }}$ day. $($ Bar $=\mathbf{2 5 \mu m})$ 




Fig. (2): A flow cytometry chart showing single parameter histogram for CD105 (A), CD13 (B) and CD45 (C).

\section{Immunophenotype Characterization:}

Immunophenotype characterization was performed for the positive and negative stem cell markers at passage 3 . The flow cytometric analysis showed positive reactions of CD105 (96.3\%), CD13 (92.7\%) to ADSCs while their clusters were negative for CD45 (3.9\%). (Fig. 2)

\section{Attachment of adipose derived stem cells onto coral granules:}

Scanning electron microscopy imaging (SEM) was used to examine the surface of the coral scaffold and the attachment of ADSCs on it after 2 days of seeding. The results showed that the scaffold had blebs and protrusions on its surface, and that the ADSCs attached well on the scaffold. At day two the cells are flattened or spindle shaped sending lamellipodia or cell processes anchoring the cells to the rough surface of the coral. (Fig. 3)

\section{Haematoxylin and eosin stain}

- At the $1^{\text {st }}$ week: In all groups the bone defect was filled with granulation tissue composed of inflammatory cells and blood vessels sometimes empty spaces representing decalcified coral granules appeared. New osteoid tissue was beginning to be formed at the periphery of the defect area radiating from the cavity wall in group C
- At the $4^{\text {th }}$ week: A network of thin bone trabeculae were formed enclosing wide bone marrow cavities lined by osteoblasts. Reversal line is seen separating new from old bone. Some spaces representing decalcified coral granules may be seen as in group B. The size of the formed bony trabeculae was larger in group $\mathrm{B}$ than group $\mathrm{A}$ and in group $\mathrm{C}$ than group $\mathrm{A} \& \mathrm{~B}$. The trabeculae were enclosing narrow spaces which were smaller in group $\mathrm{C}$ than those observed in groups A and B.



Fig. (3): (A) SEM image showing rough coral scaffold surface before seeding (3000X). (B) SEM image showing adipose derived stem cells (ADSCs) attached onto coral scaffold (arrow head) and sending processes (arrow) (5000X). 
- At the $8^{\text {th }}$ week: Bone trabeculae almost filled the cavity with more osteon formation and narrower marrow spaces than those in the $4^{\text {th }}$ week. Group B showed smaller marrow spaces and more osteon organization and maturation than group A. Group C showed more organized and mature osteons than the previous two groups with smaller marrow spaces. Reversal line is seen separating between the new and old bone in both group B and C. (Fig. 4)

\section{Masson's Trichrome stain:}

- At the $1^{\text {st }}$ week: the amount of collagen fibers formed in group B was more than that in group $\mathrm{A}$, and the amount formed in group $\mathrm{C}$ was more than the previous two groups with significant difference.

- At the $4^{\text {th }}$ week: the collagen fibers began to increase and to be arranged in the form of thin bone trabeculae radiating from the cavity wall. The amount of increase was more in group B than in group $\mathrm{A}$ and group $\mathrm{C}$ was more than the previous two groups with significant difference.

- At the $8^{\text {th }}$ week: marked increase in maturation occur in group Band $\mathrm{C}$ with marked decrease in the amount of collagen deposition than found at 4 weeks while group A showed increase in collagen deposition. (Fig.5 \&6) (Table 1\&2)

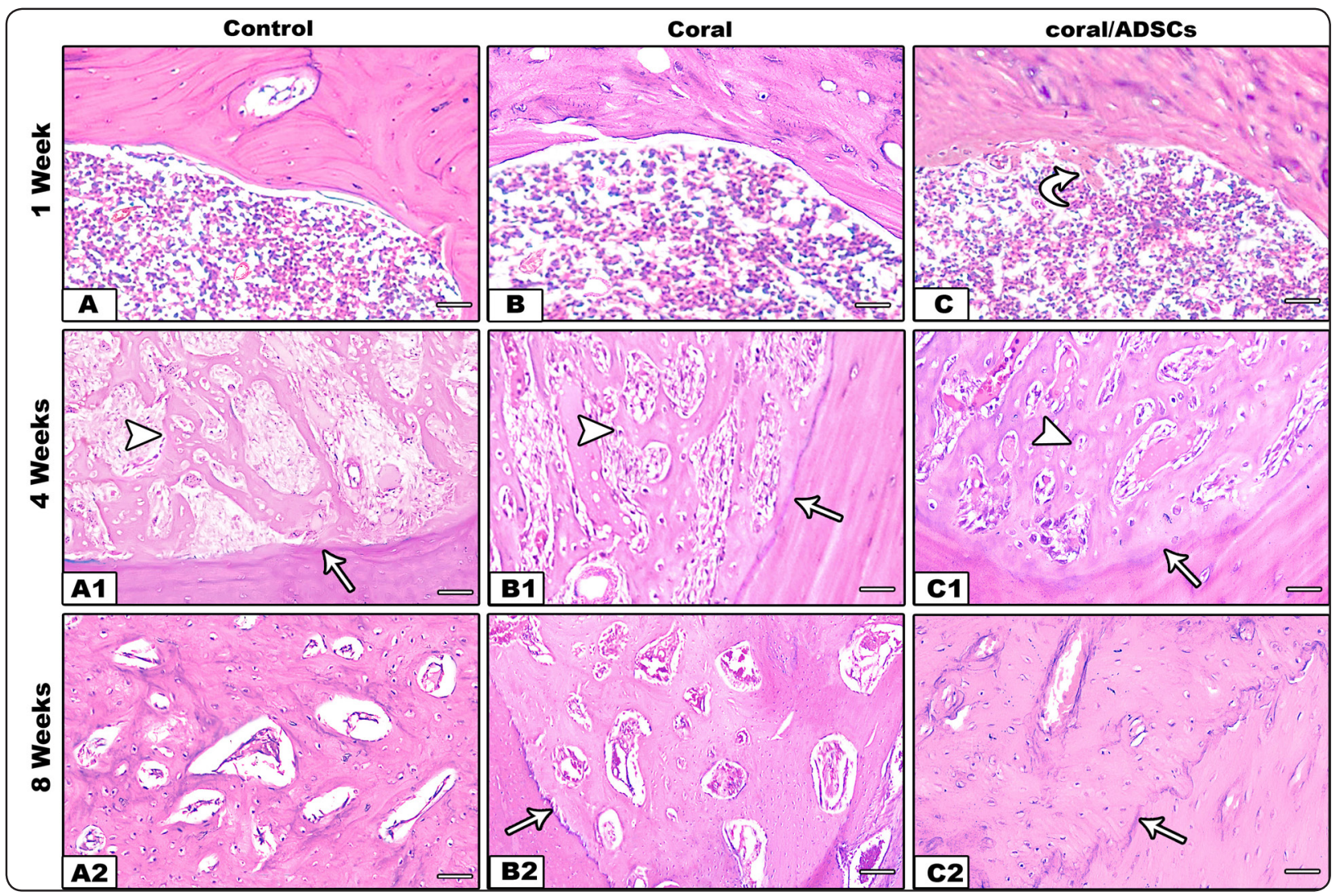

Fig. (4): Histopathological overview of the 3 study groups at different time points. At the first week the granulation tissue was filling the cavity with evidence of new bone formation at the periphery of the cavity only at the coral stem cell group (A, $B, C)$. At the forth week: network of thin bone trabeculae lined by osteoblasts with reversal lines separating new from old bone (A1, B1, and C1). The bony trabeculae were thicker in $\mathrm{C} 1$ than in $\mathrm{A} 1 \& \mathrm{~B} 1$. The marrow spaces were smaller in $\mathrm{C} 1$ than in A1 and B1. At the eighth week: new osteon formation almost filled the cavities with narrower marrow spaces than those in the $4^{\text {th }}$ week $(A 2, B 2, C 2)$. More organized and mature osteons with smaller marrow spaces (C2). Reversal lines separating the new and old bone in B2and C2. (H\&E staining, Bar= 25 $\mu \mathrm{m})$ 




Fig. (5): Histopathological overview of the 3 study groups at different times of euthanasia. At the first week greater amount of collagen fibers in C more than A\&B. At the $4^{\text {th }}$ week: New collagen fibers increased $\&$ arranged in the form of thin bone trabeculae radiating from the cavity wall. The amount was more in $\mathrm{C} 1$ than in $\mathrm{A} 1 \& \mathrm{~B} 1$. At the $\mathbf{8}^{\text {th }}$ week: marked decrease in the amount of collagen deposition in C2 than in B2 \&A2. (Masson's Trichrome, Bar= 25um).

TABLE (1): Descriptive statistics (mean $\pm \mathrm{SD}$ ) of the collagen fibers area percentage in the three study groups

\begin{tabular}{|c|c|c|c|}
\hline Trichrome & 1 week & 4 week & 8 week \\
\hline Control & $0.40^{\mathrm{c}} \pm 0.05$ & $4.71^{\mathrm{c}} \pm 0.55$ & $5.29^{\mathrm{a}} \pm 0.60$ \\
\hline Coral & $0.59^{\mathrm{b}} \pm 0.07$ & $9.29^{\mathrm{b}} \pm 0.54$ & $0.52^{\mathrm{b}} \pm 0.06$ \\
\hline ADSC & $0.81^{\mathrm{a}} \pm 0.06$ & $12.96^{\mathrm{a}} \pm 0.83$ & $0.24^{\mathrm{b}} \pm 0.07$ \\
\hline F & $36.945^{*}$ & $120.065^{*}$ & $196.522^{*}$ \\
\hline p & $<0.001^{*}$ & $<0.001^{*}$ & $<0.001^{*}$ \\
\hline
\end{tabular}

Means with Common letters are not significant (i.e. Means with Different letters are significant)

Data was expressed by using (Mean $\pm S D)$.

F: F for ANOVA test, Pairwise comparison between each 2 groups was done using Post Hoc Test (Tukey) P: p value for comparing between the studied groups *: Statistically significant at $p \leq 0.05$ 
TABLE (2): Descriptive statistics (mean $\pm \mathrm{SD}$ ) of the collagen fibers area percentage in each studied group

\begin{tabular}{|c|c|c|c|c|c|}
\hline Trichrome & 1 week & 4 week & 8 week & F & p \\
\hline Control $(\mathbf{n}=3)$ & $0.40^{\mathrm{b}} \pm 0.05$ & $4.71^{\mathrm{a}} \pm 0.55$ & $5.29^{\mathrm{a}} \pm 0.60$ & $96.280^{*}$ & $<0.001^{*}$ \\
\hline Coral $(\mathbf{n}=3)$ & $0.59^{\mathrm{b}} \pm 0.07$ & $9.29^{\mathrm{a}} \pm 0.54$ & $0.52^{\mathrm{b}} \pm 0.06$ & $763.119^{*}$ & $<0.001^{*}$ \\
\hline SC $(\mathbf{n}=\mathbf{3})$ & $0.81^{\mathrm{b}} \pm 0.06$ & $12.96^{\mathrm{a}} \pm 0.83$ & $0.24^{\mathrm{b}} \pm 0.07$ & $667.607^{*}$ & $<0.001^{*}$ \\
\hline
\end{tabular}

Means with Common letters are not significant (i.e. Means with Different letters are significant)

Data was expressed by using (Mean \pm SD.)

F: F for ANOVA test, Pairwise comparison between each 2 groups was done using Post Hoc Test (Tukey) P: p value for comparing between the sub groups *: Statistically significant at $p \leq 0.05$.

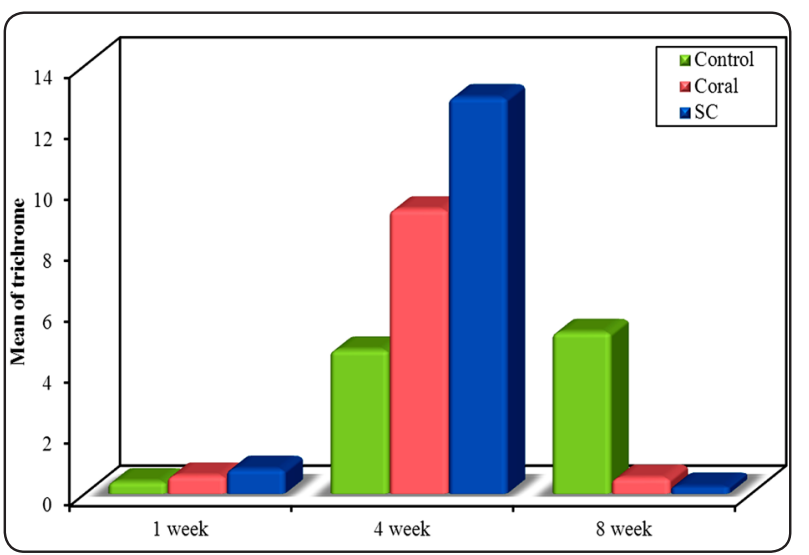

Fig. (6) Bar chart for Masson's Trichrome positively stained area percentage for different groups at different time points.

\section{DISCUSSION}

In the present study, we assessed both the ability of Acropora coral scaffolds to support ADSCs growth in vitro and the potential of such cell-containing constructs to enhance new bone formation in mandibular defects in a rat model. Our scanning electron microscope (SEM) results showed that ADSCs adhered well and sent processes when loaded on Acropora scaffold granules in vitro. This was in agreement with Puvaneswary et al (2013) who reported that Cell attachment on coral scaffold was observed to be randomly distributed and that the scaffold had roughened blebs and protrusions on its surface. ${ }^{(24)}$ Webb $\mathbf{K}$ et al (2000) also demonstrated that the behaviour of the cells on a certain scaffold such as attachment efficiency, spreading, fiber formation, and cell migration is dependent on the positive effect of the surface chemistry of the scaffold material which means that coral in this study has a positive effect on the cells . ${ }^{(25)}$

In the present study, results of $\mathrm{H} \& \mathrm{E}$ stained sections for the control group revealed normal healing sequence of the created osseous defect starting by the formation of granulation tissue followed by newly formed thin interconnecting bone trabeculae which displayed progressive thickening by the end of eight weeks. These results were in accordance with Chin et al. (2013) who studied the relationship between hypertension and healing of rat mandibular bone defects. ${ }^{(26)}$ Trejo-Iriarte et al. (2019) had reported similar findings in a study performed to evaluate bone regeneration in a critical size bone defect model in the jaw of healthy rats and the influence of gender and defect location on bone regeneration. ${ }^{(27)}$

Results obtained from coral treated group revealed that the healing process of the bone defect was better than the control group in terms of amount of bone formation, level of newly formed collagen fibers. These results were consistent with the histological results of kim et al. (2005) which used coral as bone graft substitute to treat intra-bony defects in dogs ${ }^{(28)}$ Radiological results of Emara SA et al. (2013) Showed that corals have a stimulating effect on bone healing and that more examination is 
necessary to determine bone healing at the cellular level. It also reported that ossification starts in 1-2 weeks, and defects are filled and reorganized in 6-8 weeks. ${ }^{(29)}$

It is established that, in vivo, coral scaffolds are resorbed by a combination of physicochemical dissolution attributed to enzymatic attack, especially carboanhydrase and osteoclast-like cellmediated degradation with only about $5 \%$ of the released calcium remaining at the degradation site the other $95 \%$ ending in the circulation. ${ }^{(30)}$ In the present study very minute areas of coral remnant were seen after 4 weeks which may be attributed to the granule form selected and we believe that this rate was consistent with the rate of bone formation and even it was accelerated this was in accordance with the results confirming that scaffold that enables complete bone regeneration must exhibit a rate of resorption that is finely tuned to bone apposition ${ }^{(31)}$ and also in accordance with Petite et al. (2000) who reported that in vivo resorption of coral could be detected radiographically after a few weeks of implantation ${ }^{(32)}$, other study also reported that The rapid degradation of coral diminish the potential risks associated with long-term foreign-body sequestration..$^{(33)}$

The presence of calcium, resulting from the degradation of the coral could favor local osteoblast proliferation and differentiation, extracellular matrix mineralization, and increase expression of growth factors (34) $^{(34)}$

Coral scaffold also contain magnesium as a part of its chemical composition. It also has a role in enhancing the osteogenic differentiation of ADSCs, as revealed in a study by Cecchinato et al. (2015), where magnesium was used as coating for mesoporous titania. The alkaline phosphatase activity test results of the same study revealed the osteogenic potential of magnesium. It also revealed that coral provides high concentration of phosphate at the sites of mineral depositions. ${ }^{(35)}$
Meanwhile, it is noteworthy that degradation rate of coral was variable. The difference in foreign body response as well as osteoclast recruitment and activity in the recipient may account for the variable degradation of coral between several studies. ${ }^{(36)}$ It was reported also that difference in cutting direction may be responsible for the variation of mechanical properties in each coral product. ${ }^{(30)}$ This is why we used coral in the granule form as the cavity formed is not a large one also as a trial to speed up the degradation rate and also to give enough space to be satisfactory for stem cells, osteoblasts and vascular invasion.

Regarding coral plus ADMSCs treated group, we found that the healing process was better at all-time points regarding the quality and quantity of bone that exceeded those of the control and coral groups. Masson Trichrome stain results of coral combined with stem cells at the first weeks showed that collagen fiber deposition was more than that in coral group thus supporting the idea of the synergic effect between ADSCs and coral. This was consistent with the results of Hou et al. (2007) where ADSCs seeded onto coral were used to repair a cranial defect in rabbits. ${ }^{.37)}$

The enhanced osteogenesis in this group may be attributed to several factors the first one is the use of ADSC as it was purposed that the initial presence of MSCs stimulates bone formation by inducing vascularization. Byung-Jae Kang et al. (2010) studies showed that bone matrix deposits formed by ADSC was larger than those formed by other MSCs like BMMSC and umbilical cord stem cells. ADMSCs may also affect bone formation by releasing factors that stimulated the induction and migration of cells in the surrounding bone. ${ }^{(38)}$

Our study emphasize the importance of the combination of suitable scaffold with the appropriate cell type for bone regeneration, coral granules offered good biocompatible medium for cell attachment, proliferation, ECM deposition which supported in vivo bone regeneration, it offered also a good rate 
of calcium release due to rapid degradation which improve the osteogenesis process together with the stem cells. These results were in accordance with Birk et al. (2006) who observed that preadipocytes grown on coral scaffold differentiated into boneforming cells without addition of any bone morphogenesis inducers. . $^{(39)}$

\section{CONCLUSION}

In conclusion, the current study demonstrates that addition of ADSCs to coral granules have synergistic effect on osteogenesis and could enhance the repair process of mandibular bone defects in rat model.

\section{Declarations}

- Funding: The research didn't receive any specific grant from funding agencies in the public, commercial, or not for profit sectors.

- Conflict of Interest: The authors declare that they have no conflict of interest.

- Ethical committee approval: All the experimental procedures were performed in accordance with Mansoura University research ethics committee with ethical committee approval number M0409109, and according to NIH guide for the care and use of laboratory -animals' eighth edition 2011. The study was conducted in experimental animal study laboratory of Mansoura University.

\section{HIGHLIGHTS}

- Large bone defects need scaffold for rapid healing.

- Coral scaffold contains calcium and magnesium that could enhance osteogenesis.

- Addition of adipose stem cells to coral enhanced osteogenesis in bone defects.

- The bone formation and maturation were enhanced as revealed by trichrome results.

\section{REFERENCES}

1. Eleftheriadis E, Leventis MD, Tosios KI, Faratzis G, Titsinidis S, Eleftheriadi I, Dontas I. (2010). Osteogenic activity of $\beta$-tricalcium phosphate in a hydroxyl sulphate matrix and demineralized bone matrix: a histological study in rabbit mandible: Journal of Oral Science, 52(3), 377-84.

2. Jin SC, Kim SG, Oh JS, Lee SY, Jang ES, Piao ZG, Lim SC, Jeong MA, Kim JS, You JS, Park SC, Cho YS, Yang SS, Yu SK. (2013). A comparative study of bone formation following grafting with different ratios of particle dentin and tricalcium phosphate combinations: Journal of Biomedical Nanotechnology, 9(3), 475-8.

3. Pountos I, Giannoudis PV. (2016). Is there a role of coral bone substitutes in bone repair?: Injury, 47(12), 2606-13.

4. Sergeeva N, Britaev T, Sviridova I, Akhmedova S, Kirsanova V, Popov A, Antokhin A, Frank G, Kaprin A. (2014). Scleractinium coral aquaculture skeleton: a possible 3D scaffold for cell cultures and bone tissue engineering: Bulletin of experimental biology and medicine, 156(4), 504-8.

5. Janicki P, Schmidmaier G.(2011). What should be the characteristics of the ideal bone graft substitute? Combining scaffolds with growth factors and/or stem cells: Injury, 42 Suppl 2:S77-81.

6. Tran CT, Gargiulo C, Thao HD, Tuan HM, Filgueira L, Michael Strong D. (2011). Culture and differentiation of osteoblasts on coral scaffold from human bone marrow mesenchymal stem cells: Cell Tissue Bank, 12(4), 247-61.

7. Neto AS, Ferreira JM.(2018). Synthetic and marine-derived porous scaffolds for bone tissue engineering: Materials, 11(9), 1702.

8. Lindroos B, Suuronen R, Miettinen S.(2011). The potential of adipose stem cells in regenerative medicine: Stem Cell Reviews and Reports, 7(2), 269-91.

9. Konno M, Hamabe A, Hasegawa S, Ogawa H, Fukusumi T, Nishikawa S, Ohta K, Kano Y, Ozaki M, Noguchi Y.(2013). Adipose-derived mesenchymal stem cells and regenerative medicine: Development, growth \& differentiation, 55(3), 309-18.

10. Bajek A, Gurtowska N, Olkowska J, Kazmierski L, Maj M, Drewa T. (2016). Adipose-derived stem cells as a tool in cell-based therapies: Archivum Immunologiae et Therapiae Experimentalis, 64(6), 443-54.

11. J Salgado A, L Reis R, Sousa N, M Gimble J.(2010). Adipose tissue derived stem cells secretome: soluble factors 
and their roles in regenerative medicine: Current stem cell research \& therapy, 5(2), 103-10.

12. Tobita M, Orbay H, Mizuno H.(2011). Adipose-derived stem cells: current findings and future perspectives: Discovery medicine, 11(57),160-70.

13. Vériter S, André W, Aouassar N, Poirel HA, Lafosse A, Docquier P-L, Dufrane D.(2015). Human adipose-derived mesenchymal stem cells in cell therapy: safety and feasibility in different" hospital exemption" clinical applications: PloS one, 10(10), 0139566.

14. Faul F, Erdfelder E, Lang A-G, Axel Buchner. (2007). A: G*Power 3: A flexible statistical power analysis program for the social, behavioral, and biomedical sciences: Behav Res Methods, 39,175-91.

15. Levi B, James AW, Nelson ER, Hu S, Sun N, Peng M, Wu J, Longaker MT. (2011). Studies in adipose-derived stromal cells: migration and participation in repair of cranial injury after systemic injection: Plastic and reconstructive surgery, 127(3), 1130-40.

16. Nandi SK, Kundu B, Mukherjee J, Mahato A, Datta S, Balla VK.(2015). Converted marine coral hydroxyapatite implants with growth factors: in vivo bone regeneration: Materials science and engineering, 49, 816-23.

17. Geng W, Ma D, Yan X, Liu L, Cui J, Xie X, Li H, Chen F.(2013). Engineering tubular bone using mesenchymal stem cell sheets and coral particles: Biochemical and Biophysical Research Communications, 433(4), 595-601.

18. Green DW, Lai W-F, Jung H-S.(2014). Evolving marine biomimetics for regenerative dentistry: Marine drugs, 12(5), 2877-912.

19. Kuhbier JW, Weyand B, Radtke C, Vogt PM, Kasper C, Reimers K.( 2010) Isolation, characterization, differentiation, and application of adipose-derived stem cells: Advances in Biochemical Engineering/Biotechnology,123, 55-105.

20. Liu G, Zhang Y, Liu B, Sun J, Li W, Cui L.(2013). Bone regeneration in a canine cranial model using allogeneic adipose derived stem cells and coral scaffold: Biomaterials, 34(11), 2655-64.

21. Keating A.(2012). Mesenchymal stromal cells: new directions: Cell stem cell, 10(6), 709-16.

22. Wen C, Yan H, Fu S, Qian Y, Wang D, Wang C.(2016). Allogeneic adipose-derived stem cells regenerate bone in a critical-sized ulna segmental defect: Experimental Biology and Medicine, 241(13), 1401-9.
23. Sun C, Müller E, Meffert M, Gerthsen D.(2018). On the progress of scanning transmission electron microscopy (STEM) imaging in a scanning electron microscope: Microscopy and Microanalysis, 24(2), 99-106.

24. Puvaneswary S, Raghavendran HRB, Ibrahim NS, Murali MR, Merican AM, Kamarul T.(2013). A comparative study on morphochemical properties and osteogenic cell differentiation within bone graft and coral graft culture systems: International journal of medical sciences, 10(12), 1608.

25. Webb K, Hlady V, Tresco PA.(2000) Relationships among cell attachment, spreading, cytoskeletal organization, and migration rate for anchorage-dependent cells on model surfaces: Journal of Biomedical Materials Research, 49(3), 362-8.

26. Chin VKL, Shinagawa A, Naclerio-Homem MdG.(2013). Bone healing of mandibular critical-size defects in spontaneously hypertensive rats: Brazilian oral research, 27(5), 423-30.

27. Trejo-Iriarte CG, Serrano-Bello J, Gutiérrez-Escalona R, Mercado-Marques C, García-Honduvilla N, Buján-Varela J, Medina LA.(2019). Evaluation of bone regeneration in a critical size cortical bone defect in rat mandible using microCT and histological analysis: Archives of Oral Biology, 101, 165-71.

28. Kim CS, Choi SH, Cho KS, Chai JK, Wikesjö UM, Kim CK.(2005). Periodontal healing in one-wall intra-bony defects in dogs following implantation of autogenous bone or a coral-derived biomaterial: Journal of clinical periodontology, 32(6), 583-9.

29. Emara S, Gadallah S, Sharshar A.(2013) Evaluation of coral wedge and composite as bone graft substitutes to induce new bone formation in a dog tibial defect: J Am Sci, 9(7), 526-37.

30. Allemand D, Tambutté É, Zoccola D, Tambutté S.(2011) Coral calcification, cells to reefs in: Dubinsky, Stambler N,editors. Coral reefs: An Ecosystem in Transition.Netherlands: Springer, (pp.119-50).

31. Surmenev RA, Surmeneva MA, Ivanova AA.(2014). Significance of calcium phosphate coatings for the enhancement of new bone osteogenesis-a review: Acta biomaterialia, 10(2), 557-79.

32. Petite H, Viateau V, Bensaid W, Meunier A, de Pollak C, Bourguignon M, Oudina K, Sedel L, Guillemin G. (2000). Tissue-engineered bone regeneration: Nature biotechnology, 18(9), 959-63. 
33. Polo-Corrales L, Latorre-Esteves M, Ramirez-Vick JE. (2014). Scaffold design for bone regeneration: Journal of nanoscience and nanotechnology, 14(1), 15-56.

34. Yuan H, Fernandes H, Habibovic P, de Boer J, Barradas AM, de Ruiter A, Walsh WR, van Blitterswijk CA, de Bruijn JD.(2010). Osteoinductive ceramics as a synthetic alternative to autologous bone grafting: Proceedings of the National Academy of Sciences, 107(31), 13614-9.

35. Cecchinato F, Karlsson J, Ferroni L, Gardin C, Galli S, Wennerberg A, Zavan B, Andersson M, Jimbo R.(2015). Osteogenic potential of human adipose-derived stromal cells on 3-dimensional mesoporous $\mathrm{TiO} 2$ coating with magnesium impregnation: Materials science and engineering, 52, 225-34.

36. Rosa V, Della Bona A, Cavalcanti BN, Nör JE. (2012). Tissue engineering: from research to dental clinics: Dental Materials, 28(4), 341-8.
37. Hou R, Chen F, Yang Y, Cheng X, Gao Z, Yang HO, Wu W, Mao T. (2007). Comparative study between coralmesenchymal stem cells-rhBMP-2 composite and autobone-graft in rabbit critical-sized cranial defect model: Journal of Biomedical Materials Research Part A, 80(1), 85-93.

38. Byeon Y-E, Ryu H-H, Park SS, Koyama Y, Kikuchi M, Kim WH, Kang K-S, Kweon O-K.(2010). Paracrine effect of canine allogenic umbilical cord blood-derived mesenchymal stromal cells mixed with beta-tricalcium phosphate on bone regeneration in ectopic implantations: $\mathrm{Cy}-$ totherapy, 12(5), 626-36.

39. Birk RZ, Abramovitch-Gottlib L, Margalit I, Aviv M, Forti E, Geresh S, Vago R.(2006). Conversion of adipogenic to osteogenic phenotype using crystalline porous biomatrices of marine origin: Tissue engineering, 12(1), 21-31. 